\title{
Non-Human Protein
}

National Cancer Institute

\section{Source}

National Cancer Institute. Non-Human Protein. NCI Thesaurus. Code C20158.

Proteins from organisms other than human. 